\title{
DETECTION OF TMPRSS2-ERG FUSION TRANSCRIPT IN BIOPSY SPECIMEN OF PROSTATE CANCER PATIENTS: A SINGLE CENTRE EXPERIENCE
}

\author{
Aleksandar Trifunovski ${ }^{1}$, Aleksandar Dimovski ${ }^{2}$, Sasho Dohcev ${ }^{1}$, Sotir Stavridis ${ }^{1}$, \\ Oliver Stankov ${ }^{1}$, Skender Saidi', Marija Gjorgjievska ${ }^{1}$, Zivko Popov ${ }^{1,2}$ \\ ${ }^{1}$ University Clinic of Urology, Skopje, R. N. Macedonia \\ ${ }^{2}$ Research Centre for Genetic Engineering and Biotechnology "Georgi D. Efremov", \\ Macedonian Academy of Sciences and Arts, Skopje, R. N. Macedonia
}

Corresponding author: Aleksandar Trifunovski, University Clinic of Urology, Vodnjanska St. 17, 1000 Skopje, R. N. Macedonia, Tel.0038970341010, E-mail : trifunovskia@gmail.com

\section{ABSTRACT}

Introduction: Prostate carcinoma is the most frequent malign neoplasm among men with an ever- growing incidence rate. TMPRSS2-ERG fusion transcript leads to the androgen induction of ERG proto-oncogenes expression, representing a high presence of oncogenes alteration among prostate tumour cells.

Aim: The aim of this research was to detect and evaluate theTMPRSS2-ERG fuse transcript in the tissues of patients with prostate cancer, and establish a base of material of these samples for further genetic examination.

Materials and methods: The research was a prospective clinical study that involved and focused on random sampling of 101 patients (62 with prostate cancer-study group and 39 with benign changes in the prostate-control group). Real time PCR analysis for detection of the TMPRSS2-ERG fusion transcript in prostate tissue was performed and also data from the histopathology results of tissues were used, as well as data for the level of PSA (prostate-specific antigen) in blood.

Results: TMPRSS2-ERG fusion transcript was detected in 20 out of $62(32.2 \%)$ patients with prostate carcinoma and among no patients with benign changes whatsoever. There were no significant differences between patients with/without detected TMPRSS2-ERG fusion related to Gleason score. Among 50\%, in the study group this score was greater than 7 per/for Median IQR=7 (6-8). Significant difference was recognized, related to the average value of PSA in favour of significantly higher value of PSA in the study group with prostate cancer, but there was also no significant difference between samples with prostate cancer who were with/without detected TMPRSS2-ERG fusion transcript related to PSA level.

Discussion: The results from this research are in accordance with the values and results from analyses done in several research centres and oncological institutes.

Conclusion: The positive findings in small scale studies encourage the implementation of larger scale studies that will be enriched with results of genetic transcript in blood and urine and will define the positive diagnostic meaning of the TMPRSS-ERG fusion transcript.

Keywords: TMPRSS2-ERG, diagnose, prostate carcinoma 


\section{INTRODUCTION}

Prostate carcinoma, according to the frequency of incidence, is the fifth malign disease in the world and it is the most frequent type of carcinoma among the male population. $11.7 \%$ of all the recently diagnosed carcinoma are prostate carcinoma. The incidence of this type of cancer is continually increasing due to the life span prolongation and the introduction of new diagnostic methods, such as the PSA test (prostate - specific antigen test), transrectal ultrasonography and magnetic resonance [1-8]. Worldwide, there is a difference in the distribution of prostate carcinoma among various parts of the globe, which is partially due to the migration processes of the world population [2].

The chances of the incidence of this disease abruptly increase with age and they are significantly greater after the age of 50. Prostate carcinoma incidence is the highest in the USA, Canada and the Scandinavian countries, and it is the lowest in China and other Asian countries. The variability in distribution of this disease in the world is due to the genetics differences, the lifestyle, the quality of the health system or a combination of all these factors. The incidence rate is the highest among Afro-Americans, and it is the lowest among the population in Eastern Asia. A greater number of new cases of this disease is registered among the black male population, which is usually in a more aggressive form compared to the Caucasian population [9-21].

Research done in the USA has shown that the mortality rate among Afro-Americans is five times higher than among people of the yellow race; it is three times higher than the mortality rate among Latin-Americans and twice higher than the one among the Caucasian population. There is solid evidence that androgens influence the aetiology of this type of carcinoma. A fact supporting this claim is that this type of carcinoma does not occur among eunuchs and men who have been castrated, and the androgen ablation leads to remission of this disease [22].

The reasons for the continuing increasing incidence of the prostate carcinoma prevalence have not been clarified yet. However, several possible reasons are the following [23-26]:

a) ageing population; b) disease awareness among the medical staff, as well as among population in general; c) improvement of screening tests (PSA, Transrectal ultrasonography-TRUS and prostate bi- opsy) and d) the increased implementation of the PSA test as a screening method.

Apart from the prostate - specific antigen (PSA), as the most widely used tumour marker for the detection of prostate carcinoma on its own or combined with its derivates, there are other markers which are used in diagnostic purposes at a greater or minor success rate. TMPRSS2-ERG fusion transcript leads to the androgen induction of ERG proto-oncogenes expression representing a high presence of oncogenes alteration among prostate tumour cells. This transcript has a significant incidence in the human prostate cancer and can be non-invasively detected in urine, and it is also detected in blood and tissue.

\section{AIM}

The aim of this research was to detect and evaluate the TMPRSS2-ERG fusion transcript in the tissues of patients with prostate cancer, and establish a base of material of these samples for further genetic examination.

\section{MATERIALS AND METHODS}

The research was a prospective clinical study which was realized in the period of two years, 2018 and 2019, at the University Clinic of Urology - Skopje in cooperation with the Institute for Pathological Anatomy - Skopje and the Clinical Biochemistry at the Faculty of Medicine- Skopje; and the Research centre for genetic engineering and biotechnology "Georgi D. Efremov" at the MASA (Macedonian Academy of Sciences and Arts).

\section{Patient data}

The research study employed a random sample of 101 patients (62 with prostate carcinoma - study group and 39 with prostate benign changes - control group). The inclusive criteria involved: men at the age of $\geq 40$ and $\leq 85$, the socio-demographic features being irrelevant; PSA $>4 \mathrm{ng} / \mathrm{ml}$ and/or positive rectal toucher (suspect digito-rectal examination). Patients with other types of malignant diseases, severe general and locoregional disease, incurable condition, demention, rational judgement disorder, more serious cardiovascular diseases and coagulopatias were excluded from this study. 


\section{Material used}

The prostate biopsy tissue material was used in this research. Apart from materials for molecular analysis (tissue), data from the histopathology results of tissues (with Gleason score data) were used, as well as data for the level of prostate specific antigen (PSA) in blood.

\section{Method implemented}

The samples of the prostate tissue were taken by a biopsy in accordance with the routine methods and procedures, i.e. at least 10-12 "core" biopsies (+ 1-2 cylinders) $10-20 \mathrm{~mm}$ in length: 2 from the prostate apex, 2 from the base and 6-8 from the middle of the peripheral zone of the prostate (5-6 from both sides of the prostate). One additional cylinder from the suspect area was taken for molecular analysis. This cylinder was placed in 1,5 $\mathrm{ml}$ Eppendorf tube, than submerged and snap-frozen in liquid nitrogen and stored on a temperature of -80 degrees Celsius until the start of further analysis at the laboratory in MASA. If a certain sample of the biopic material was inadequate (insufficiently long) the biopsy procedure in that region was routinely repeated. Immediately upon the biopsy procedure, the prostate tissue was placed in a $10 \%$ formalin container, so as to prevent tissue autolysis. In addition, the material was processed in four different reagents, upon which it was moulded with paraffin, cut and finally processed in Hematoxylin and Eosin colours for histopathology and a "Gleason" assessment.

During the molecular analysis, approximately $10 \mathrm{mg}$ of each tissue sample was used for total RNA extraction, which was performed on an automated platform (MagCore ${ }^{\circledR}, \mathrm{RBC}$ Bioscience, Taiwan) and a commercial kit (MagCoretriXact RNA Kit) which included DNase treatment for DNA elimination. For detection of the mutant and the wild-type alleles, a real time PCR analysis was performed using KiCqStart One-Step Probe RT-qPCR Kit (Sigma-Aldrich, Missouri, USA), TaqMan $\AA$ fusion assay and a TaqMan ${ }^{\circledR}$ gene expression assay (Applied Biosystems $^{\mathrm{TM}}$, Massachusetts, USA), following manufacturer's protocol. The fluorescent RT-PCR reaction was performed on 7500 Fast Real-Time PCR Systems using FAM dye for the detection of the fusion and VIC dye for the detection of the control transcript. The cycling conditions and threshold levels were set as recommended by the manufacturer. The fusion assay resulted in 106bp fragment containing TMPRSS2 exon 1 and ERG exon 4, while the control gene expression assay resulted in $79 \mathrm{bp}$ fragment containing exons $7-8$ of the TMPRSS2 gene. This duplex assay has a declared detection limit of $0.05 \%$ for the detection of TMPRSS2-ERG exon1-exon4 isoform, however, this assay would also detect fusion transcripts involving other TMPRSS2 exons linked to the exons located 5 ' of the exon 4 from the ERG gene.

\section{Approval and consent}

The participation in this research was on a voluntary basis, and it was approved by the Ethics Commission of the Medical Faculty at "Ss. Cyril and Methodius" University - Skopje.

\section{Statistics analysis}

Data was statistically analysed in SPSS software package, version 22.0 for Windows (SPSS, Chicago, IL, USA). The qualitative series were processed by determining the coefficient of relations, proportions, and rates, and were shown as absolute and relative numbers. Quantitative series were analysed with measures of central tendency (average, median), as well as with dispersion measures (standard deviation, standard error). Normality of distribution was tested by Shapiro-Wilk W test. Mann-Whitney U Test was used for analysis of differences between the two numerical variables. A two-sided analysis with a significance level of $p<0,05$ was used to determine the statistical significance.

\section{RESULTS AND DISCUSSION}

The frequency of the TMPRSS2-ERG fusion transcript in consecutive series of study and control group were evaluated. TMPRSS2-ERG fusion was detected in $32.2 \%$ (20 out of 62 samples) in a study group with prostate cancer (Table 1) and among no cases with benign changes whatsoever (Table 2).

A Gleason Score (Gleason Major \& Gleason Minor) was determined for every patient with prostate carcinoma. (Table 1) The average values of Gleason Major was 3.4 \pm 0.6 , whereas those of Gleason Minor was 3.5 \pm 0.6 . Among $50 \%$ of cases in the study group these scores were greater than 3 for Median IQR=3 (3-4). The average Gleason Score was $7 \pm 0.9$ with $\mathrm{min} / \mathrm{max}$ value of $6(3+3) / 9(4+5,5+4)$. Among $50 \%$ in the study group this score was greater than 7 per/for Median IQR=7 (6-8). There were no significant differences between patients with/without detect- 
ed TMPRSS2-ERG fusion transcript related to Gleason Major (Mann-Whitney U test: $Z=1.807$; $\mathrm{p}=0 ., 071$ ), Gleason Minor (Mann-Whitney U test: $Z=-0.437 ; p=0.662$ )as well as Gleason Score (Mann-Whitney U test: $Z=1.1745 ; \mathrm{p}=0.242$ ).

The average value of PSA among samples with prostate carcinoma was $32.2 \pm 38.05 \mathrm{ng} / \mathrm{ml}$, with $\mathrm{min} / \mathrm{max}$ value of $4.3 / 152 \mathrm{ng} / \mathrm{ml}$ for Median IQR=15 (8.5-45) (Table 1). The average value of PSA in the control group was $11.7 \pm 11.4$ with $\mathrm{min} /$ $\max$ value of $4.2 / 68 \mathrm{ng} / \mathrm{ml}$ for Median IQR=7.4 (5.8-14) (Table 2). There was a significant difference between the two groups related to PSA value (Mann-Whitney U Test: $Z=-3.781 ; p=0.0002$ ) in

Table 1. Qualitative TMPRSS2 - ERG RT-PCR among patients with prostate carcinoma

\begin{tabular}{|c|c|c|c|c|c|c|c|c|c|c|c|c|c|}
\hline 䒕 & $\stackrel{8}{4}$ & ఓు & $\sum_{0}^{\pi}$ & $\sum_{0}^{\mathcal{E}}$ & 3 & 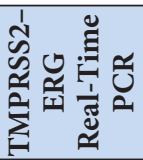 & 节 & $\stackrel{8}{4}$ & 岕 & $\sum_{0}^{\pi}$ & $\sum_{0}^{J}$ & Uి & 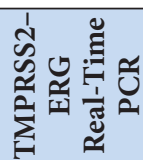 \\
\hline $\mathrm{CaP}-1$ & 62 & 9,7 & 3 & 2 & 6 & $\begin{array}{c}\text { Negative, } \\
\text { type }\end{array}$ & $\mathrm{Ca} \mathrm{P}-32$ & 50 & 12,2 & 3 & 3 & 6 & $\begin{array}{c}\text { Positive, } \\
\text { type * }\end{array}$ \\
\hline $\mathrm{Ca} P$ - 2 & 66 & 7,3 & 3 & 4 & 7 & $\begin{array}{l}\text { Negative, } \\
\text { type }\end{array}$ & Ca $P-33$ & 66 & 6,1 & 3 & 3 & 6 & $\begin{array}{c}\text { Negative, } \\
\text { type }\end{array}$ \\
\hline $\mathrm{Ca} P-3$ & 63 & 32 & 4 & 4 & 8 & $\begin{array}{l}\text { Negative, } \\
\text { type }\end{array}$ & $\mathrm{Ca} P-34$ & 53 & 70 & 3 & 4 & 7 & $\begin{array}{c}\text { Positive, } \\
\text { type }\end{array}$ \\
\hline Ca P-4 & 74 & 16,5 & 4 & 5 & 9 & $\begin{array}{c}\text { Negative, } \\
\text { type }\end{array}$ & Ca P -35 & 62 & 7.4 & 3 & 3 & 6 & $\begin{array}{l}\text { Negative, } \\
\text { type }\end{array}$ \\
\hline $\mathrm{Ca} P-5$ & 74 & 84 & 3 & 4 & 7 & $\begin{array}{c}\text { Negative, } \\
\text { type }\end{array}$ & Ca $P-36$ & 69 & 116 & 4 & 5 & 9 & $\begin{array}{c}\text { Positive, } \\
\text { type }\end{array}$ \\
\hline $\mathrm{Ca} P-6$ & 64 & 8.3 & 3 & 3 & 6 & $\begin{array}{c}\text { Negative, } \\
\text { type }\end{array}$ & $\mathrm{Ca} \mathrm{P}-37$ & 64 & 148 & 4 & 3 & 7 & $\begin{array}{c}\text { Negative, } \\
\text { type }\end{array}$ \\
\hline $\mathrm{Ca} P-7$ & 71 & 7,4 & 3 & 4 & 7 & $\begin{array}{c}\text { Positive, } \\
\text { type * }\end{array}$ & $\mathrm{Ca} P-38$ & 77 & 150 & 4 & 3 & 7 & $\begin{array}{c}\text { Negative, } \\
\text { type }\end{array}$ \\
\hline $\mathrm{Ca} \mathrm{P}-8$ & 78 & 17 & 3 & 4 & 7 & $\begin{array}{c}\text { Negative, } \\
\text { type }\end{array}$ & $\mathrm{Ca} P$ - 39 & 65 & 4,7 & 3 & 4 & 7 & $\begin{array}{c}\text { Negative, } \\
\text { type }\end{array}$ \\
\hline $\mathrm{Ca} \mathrm{P}-9$ & 64 & 45 & 4 & 4 & 8 & $\begin{array}{c}\text { Positive, } \\
\text { type * }\end{array}$ & $\mathrm{Ca} \mathrm{P}-40$ & 61 & 7.1 & 3 & 4 & 7 & $\begin{array}{c}\text { Negative, } \\
\text { type }\end{array}$ \\
\hline Ca P-10 & 72 & 20,1 & 3 & 3 & 6 & $\begin{array}{c}\text { Negative, } \\
\text { type }\end{array}$ & Ca P-41 & 80 & 90 & 5 & 4 & 9 & $\begin{array}{c}\text { Negative, } \\
\text { type }\end{array}$ \\
\hline $\mathrm{Ca} P-11$ & 64 & 4,3 & 3 & 3 & 6 & $\begin{array}{c}\text { Positive, } \\
\text { type * }\end{array}$ & $\mathrm{Ca} P-42$ & 72 & 16,4 & 4 & 3 & 7 & $\begin{array}{c}\text { Negative, } \\
\text { type }\end{array}$ \\
\hline $\mathrm{CaP}-12$ & 68 & 5,2 & 3 & 3 & 6 & $\begin{array}{c}\text { Positive, } \\
\text { type * }\end{array}$ & $\mathrm{Ca} P-43$ & 75 & 14,5 & 3 & 3 & 6 & $\begin{array}{c}\text { Negative, } \\
\text { type }\end{array}$ \\
\hline $\mathrm{Ca} \mathrm{P}-13$ & 59 & 9,1 & 4 & 3 & 7 & $\begin{array}{c}\text { Positive, } \\
\text { type * }\end{array}$ & $\mathrm{Ca} P-44$ & 62 & 7,6 & 5 & 3 & 8 & $\begin{array}{c}\text { Negative, } \\
\text { type }\end{array}$ \\
\hline $\mathrm{CaP}-14$ & 70 & 8,5 & 3 & 3 & 6 & $\begin{array}{l}\text { Negative, } \\
\text { type }\end{array}$ & $\mathrm{Ca} P-45$ & 72 & 8 & 3 & 4 & 7 & $\begin{array}{c}\text { Negative, } \\
\text { type }\end{array}$ \\
\hline $\mathrm{CaP}-15$ & 74 & 14 & 4 & 3 & 7 & $\begin{array}{l}\text { Negative, } \\
\text { type }\end{array}$ & $\mathrm{Ca} P-46$ & 76 & 21,3 & 3 & 3 & 6 & $\begin{array}{c}\text { Negative, } \\
\text { type }\end{array}$ \\
\hline $\mathrm{Ca} P-16$ & 61 & 4,5 & 3 & 3 & 6 & $\begin{array}{l}\text { Negative, } \\
\text { type }\end{array}$ & $\mathrm{Ca} P-47$ & 77 & 8,5 & 4 & 5 & 9 & $\begin{array}{c}\text { Negative, } \\
\text { type }\end{array}$ \\
\hline $\mathrm{Ca} P-17$ & 55 & 63,5 & 4 & 4 & 8 & $\begin{array}{c}\text { Negative, } \\
\text { type }\end{array}$ & $\mathrm{Ca} P-48$ & 59 & 152 & 4 & 4 & 8 & $\begin{array}{c}\text { Negative, } \\
\text { type }\end{array}$ \\
\hline Ca P-18 & 85 & 24 & 3 & 3 & 6 & $\begin{array}{c}\text { Positive, } \\
\text { type * }\end{array}$ & Ca $\mathrm{P}-49$ & 73 & 14 & 3 & 3 & 6 & $\begin{array}{c}\text { Negative, } \\
\text { type }\end{array}$ \\
\hline Ca P - 19 & 70 & 9,4 & 3 & 3 & 6 & $\begin{array}{c}\text { Positive, } \\
\text { type * }\end{array}$ & Ca $P-50$ & 63 & 100 & 4 & 4 & 8 & $\begin{array}{c}\text { Negative, } \\
\text { type }\end{array}$ \\
\hline Ca P - 20 & 78 & 15,5 & 3 & 4 & 7 & $\begin{array}{c}\text { Positive, } \\
\text { type * }\end{array}$ & Ca $P-51$ & 77 & 7,4 & 3 & 3 & 6 & $\begin{array}{c}\text { Negative, } \\
\text { type }\end{array}$ \\
\hline Ca P - 21 & 69 & 18 & 3 & 3 & 6 & $\begin{array}{l}\text { Positive, } \\
\text { type * }\end{array}$ & $\mathrm{Ca} P-52$ & 60 & 44 & 3 & 4 & 7 & $\begin{array}{c}\text { Positive, } \\
\text { type * }\end{array}$ \\
\hline $\mathrm{Ca} P-22$ & 64 & 58,2 & 4 & 4 & 8 & $\begin{array}{l}\text { Negative, } \\
\text { type }\end{array}$ & $\mathrm{Ca} P-53$ & 80 & 45,3 & 3 & 4 & 7 & $\begin{array}{c}\text { Positive, } \\
\text { type } *\end{array}$ \\
\hline $\mathrm{Ca} P-23$ & 71 & 9,7 & 3 & 4 & 7 & $\begin{array}{c}\text { Negative, } \\
\text { type }\end{array}$ & $\mathrm{Ca} P-54$ & 64 & 12 & 3 & 3 & 6 & $\begin{array}{c}\text { Negative, } \\
\text { type }\end{array}$ \\
\hline $\mathrm{CaP}-24$ & 67 & 18 & 3 & 3 & 8 & $\begin{array}{l}\text { Negative, } \\
\text { type }\end{array}$ & $\mathrm{Ca} P-55$ & 74 & 10,2 & 4 & 3 & 7 & $\begin{array}{c}\text { Negative, } \\
\text { type }\end{array}$ \\
\hline $\mathrm{Ca} P-25$ & 74 & 70 & 4 & 4 & 8 & $\begin{array}{l}\text { Negative, } \\
\text { type }\end{array}$ & $\mathrm{Ca} P-56$ & 85 & 58 & 3 & 3 & 6 & $\begin{array}{c}\text { Negative, } \\
\text { type }\end{array}$ \\
\hline $\mathrm{Ca} P-26$ & 69 & 22,3 & 4 & 4 & 8 & $\begin{array}{l}\text { Negative, } \\
\text { type }\end{array}$ & Ca $\mathrm{P}-57$ & 75 & 25 & 3 & 4 & 7 & $\begin{array}{c}\text { Positive, } \\
\text { type * }\end{array}$ \\
\hline Ca P - 27 & 68 & 9,4 & 4 & 3 & 7 & $\begin{array}{l}\text { Negative, } \\
\text { type }\end{array}$ & $\mathrm{Ca} P-58$ & 67 & 20,5 & 4 & 3 & 7 & $\begin{array}{c}\text { Negative, } \\
\text { type }\end{array}$ \\
\hline Ca $P-28$ & 70 & 45,8 & 4 & 5 & 9 & $\begin{array}{c}\text { Negative, } \\
\text { type }\end{array}$ & Ca P -59 & 72 & 9,3 & 3 & 3 & 6 & $\begin{array}{c}\text { Positive, } \\
\text { type } *\end{array}$ \\
\hline Ca P-29 & 67 & 12,7 & 3 & 3 & 6 & $\begin{array}{c}\text { Negative, } \\
\text { type }\end{array}$ & $\mathrm{Ca} P-60$ & 74 & 6,1 & 3 & 4 & 7 & $\begin{array}{l}\text { Positive, } \\
\text { type * }\end{array}$ \\
\hline $\mathrm{Ca} P-30$ & 62 & 24 & 4 & 3 & 7 & $\begin{array}{c}\text { Negative, } \\
\text { type }\end{array}$ & $\mathrm{Ca} P-61$ & 58 & 10.3 & 3 & 3 & 6 & $\begin{array}{c}\text { Positive, } \\
\text { type }\end{array}$ \\
\hline $\mathrm{Ca} P-31$ & 64 & 94 & 4 & 4 & 8 & $\begin{array}{c}\text { Positive, } \\
\text { type * }\end{array}$ & $\mathrm{Ca} P-62$ & 65 & 5.8 & 3 & 3 & 6 & $\begin{array}{c}\text { Positive, } \\
\text { type } *\end{array}$ \\
\hline
\end{tabular}


favour of significantly higher value of PSA among the study group with prostate cancer. We didn't find a significant difference between patients with prostate cancer who were with/without detected TMPRSS2-ERG fused transcript related to PSA level (Mann-Whitney U test: $Z=0.444 ; p=0.6569$ ).
Samples with detected TMPRSS2-ERG fused transcript had no significantly different PSA level $(28.8 \pm 31.7$ with $\mathrm{min} / \max 4.3 / 116$ and Median $\mathrm{IQR}=13.8(8.3-44.5)$ vs. patients where the transcript was not detected $(33.8 \pm 41$ with $\mathrm{min} / \mathrm{max}$ 4.5/152 and Median IQR=15.4 (8.5-45.8).

Table 2. Qualitative TMPRSS2 - ERG RT-PCR among patients without prostate carcinoma

\begin{tabular}{|c|c|c|c|c|c|c|c|}
\hline & $\underset{<}{80}$ & $\underset{\omega}{\mathscr{L}}$ & 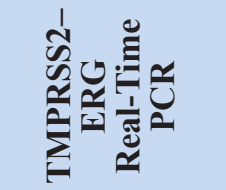 & & $\stackrel{0}{0}$ & $\underset{\mathscr{Q}}{\ll}$ & 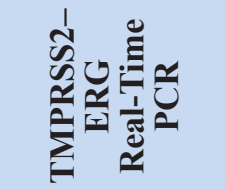 \\
\hline Be $P$ - 1 & 62 & 14.03 & Negative tvpe & Be $P-21$ & 71 & 6,4 & Negative tvpe \\
\hline Be $P-2$ & 72 & 12 & Negative tvpe & Be $P-22$ & 81 & 68,1 & Negative tvpe \\
\hline Be $\mathbf{P}-3$ & 69 & 9 & Negative, tvpe & Be $\mathbf{P}-23$ & 69 & 6,1 & Negative, type \\
\hline Be $P-4$ & 78 & 7,2 & Negative, type & Be P - 24 & 73 & 15,5 & Negative, type \\
\hline Be $P-5$ & 62 & 17,9 & Negative, type & Be $P-25$ & 64 & 9 & Negative, type \\
\hline Be $P-6$ & 74 & 6.7 & Negative type & Be $P-26$ & 68 & 5,4 & Negative type \\
\hline Be $\mathrm{P}-7$ & 66 & 5,3 & Negative, type & Be $\mathbf{P}-27$ & 71 & 7 & Negative, type \\
\hline Be $P-8$ & 68 & 7.4 & Negative, type & Be $P-28$ & 68 & 10 & Negative, type \\
\hline Be $P$ - 9 & 67 & 4.7 & Negative, type & Be P- 29 & 61 & 4,2 & Negative, type \\
\hline Be $P-10$ & 79 & 6.6 & Negative, type & Be $\mathbf{P}-\mathbf{3 0}$ & 74 & 5,8 & Negative, type \\
\hline Be P - 11 & 65 & 7,37 & Negative, type & Be P-31 & 71 & 7 & Negative, type \\
\hline Be $\mathrm{P}-12$ & 60 & 5.2 & Negative type & Be $\mathrm{P}-32$ & 71 & 16,1 & Negative type \\
\hline Be $P-13$ & 67 & 5,7 & Negative, type & Be $\mathrm{P}-33$ & 71 & 39,1 & Negative, type \\
\hline Be $\mathrm{P}-14$ & 78 & 15 & Negative, type & Be $\mathrm{P}-34$ & 67 & 5,2 & Negative, type \\
\hline Be $P-15$ & 68 & 14,9 & Negative, type & Be $\mathrm{P}-35$ & 73 & 9 & Negative, type \\
\hline Be $P-16$ & 59 & 12 & Negative, type & Be P-36 & 63 & 19 & Negative, type \\
\hline Be $\mathrm{P}-17$ & 68 & 5,6 & Negative, type & Be $\mathbf{P}-37$ & 63 & 24,5 & Negative, type \\
\hline Be $\mathrm{P}-18$ & 69 & 5.2 & Negative, type & Be $\mathrm{P}-38$ & 64 & 8,9 & Negative, type \\
\hline Be $P-19$ & 79 & 8,9 & Negative, type & Be $\mathbf{P}-39$ & 62 & 13 & Negative, type \\
\hline Be $P-20$ & 70 & 6.2 & Negative type & & & & \\
\hline
\end{tabular}
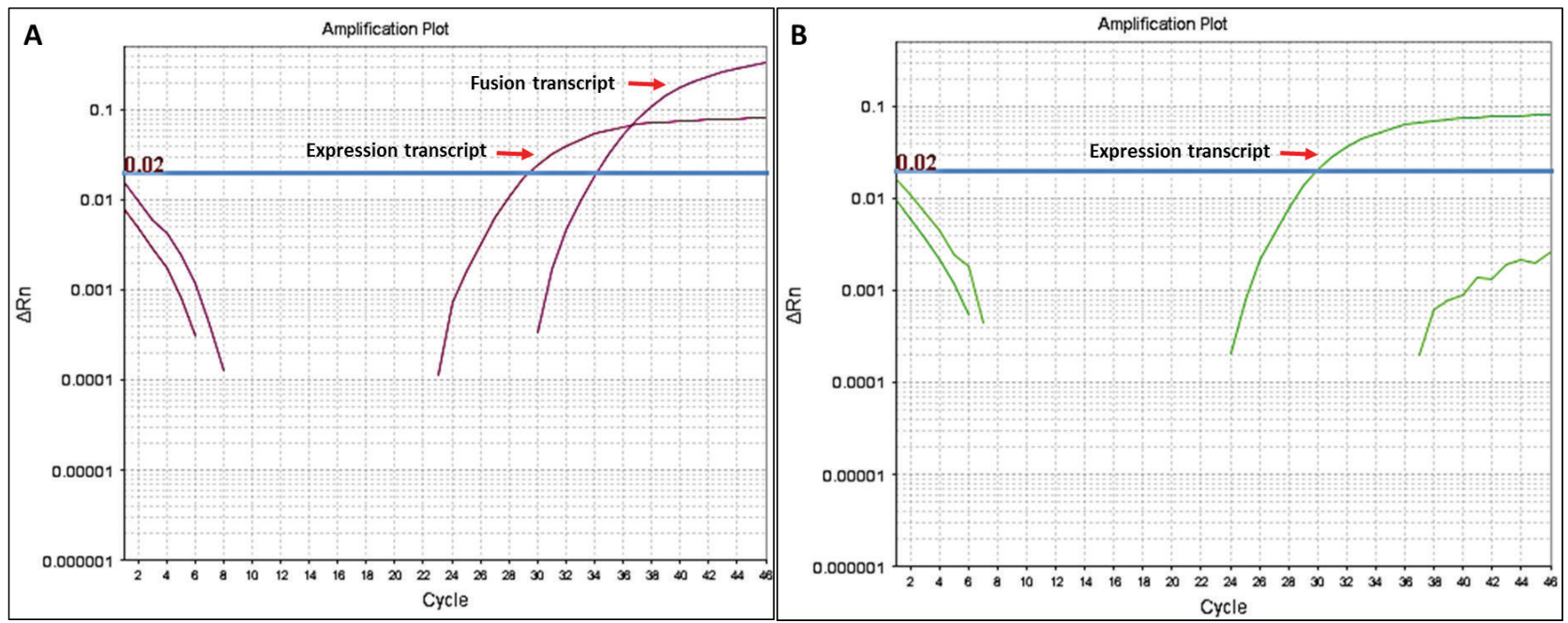

Figure 1. Real-time PCR results from a positive (A) and a negative (B) sample for TMPRSS2-ERG fusion transcript. 
The control group was age matched to the study group, the average age of patients in the whole group $(\mathrm{N}=101)$ was $68.6 \pm 6.7$ years of age with $\mathrm{min} / \mathrm{max}$ age of 50/85 years for Median $\mathrm{IQR}=68$ (64-73) (Table 1). The average age of the study group $(\mathrm{N}=62)$ was $68.8 \pm 5.6$ years with $\mathrm{min} /$ max age of 50/85 for Median IQR=68 (64-74) (Table 1), while in the control group $(\mathrm{N}=39)$ the average age was $68.4 \pm 7.3$ years with $\mathrm{min} / \mathrm{max}$ age of 59/ 81 for Median IQR=68 (64-71) $($ Table 2).

\section{DISCUSSION}

The most frequently used marker in prostate carcinoma diagnostics and detection is PSA. The level of the PSA serum rises in cases of prostate carcinoma, due to its enhanced production of tumour tissue and the disconnection of the tissue barrier between the prostate tissue and the capillary lumens [27].

Prostate cancer detection by means of measuring the level of PSA in serum means detection of the disease at an early stage on limited and localized changes in the prostate in comparison to the detection of this disease in a much more advanced stage in the period before the implementation of this antigen. [28].

Transmembrane protease, serine 2 , encodes a protein that belongs to the serine protease family. The encoded protein contains a type II transmembrane domain, a receptor of class A domain, a scavenger receptor cysteine-rich domain and a protease domain. [29].The over expression of ERG contributes to the development of an androgen independence by the breach in the signalizing towards the androgen receptor.

TMPRSS2 protein is present in the normal prostate tissue, but it is overly expressed in the neoplasm epithelium of the prostate. Research conducted among humans and animal models point out that the greater expression of ERG in tumour cells of the prostate leads to a neoplasm process through the activation of C-MYC and a disorder of the prostate epithelial differentiation [30].

Contemporary research on malignomas aims to identify genes with a certain role in the development of the malignant process. A large number of such genes are identified through analyses, which determine certain chromosome rearrangements and alterations more frequent in leukaemia, lymphomas and sarcomas usually re- sulting in the appearance and formation of fused genes [31]. This type of genetic change is rarely detected in solid tissue tumours, which can be explained by the fact that the number of studies and research done on this type of carcinoma is significantly smaller [30].

Using the bioinformatics analysis known as "Carcinoma Gene Expression Profile Analyses" the TMPRSS2-ERG, TMPRSS2-ETV1 fused genes are detected with a high presence in prostate cancer. The same ones have been previously selected, so as to demonstrate an overexpression of the erythroblastosis transforming specific transcript factor ERG, i.e.ETV1 [32].

Later, yet another one - a rare third fused gene that involves the TMPRSS2 locus and the ETV4 gene in the ETS family has been identified. The function of theTMPRSS2 protein in the prostate carcinoma genesis is based on the ETS transcript factors, such as ERG and ETV1 through a gene fusion. The fusion transcription results from a $3 \mathrm{Mb}$ interstitial deletion between these two gene loci of the 21q22 chromosome, and it is present in at least half of the prostate carcinoma [32].

A genetic anomaly was detected in over $50 \%$ of the tested series with RT-PCR in clinically localized prostate carcinoma, which defines it as the most frequent type of gene fusion in human carcinoma. In addition, the level of ERG exogenous was higher than 2.5 of all cases with TMPRSS2-ERG positive (but not among negative) prostate carcinoma. These results are in accordance with the results of the research done by Tomlins and his associates who have detected such presence by the implementation of FISH analysis of ERG gene rearrangements in a series of 29 prostate cancers selected randomly regardless of any ERG or ETV1 expression data [33].

Higher fusion frequency has been cited by Soller and his associates, but this high discrepancy is due to the small numbers of cases $(n=18)$ and/ or the use of included PCR [34].

Researches have been done and TMPRSS2-ERG fusion disorder can be detected through the RT-PCR methods in the prostate cancer patients' tissue, blood and urine [35].

In our research, the TMPRSS2-ERG fusion transcript was detected in $20(32.2 \%)$ out of 62 patients with prostate carcinoma. This finding is in accordance with the values and results from analyses done in several research centres. In studies and research done at the oncologi- 
cal institutes in European genetics centres the significant proportion of prostate cancer with TMPRSS2-ERG genetic rearrangements and alterations has been confirmed.

Mehra et al. found that TMPRSS2-ERG mRNA expression was present in 10 of $27(37 \%)$ of hormone-refractory metastatic prostate cancer patient samples[36], and in the research of cases defined as localized prostate cancer, Liu B et al. concluded that TMPRSS2-ERG fusion was positive in $28.0 \%(14 / 50)$ [37]. The prevalence of TMPRSS2:ERG varied according to several factors. In the meta-analysis realized by Pettersson et al. in the USA, the prevalence of the fusion was $30 \%$ in a tissue from TURP samples and patients diagnosed by TURP were slightly more suggestive of associations with poor outcomes. Men whose tumours were fusion positive were well over 2 times as likely to be diagnosed with cancers at a higher clinical stage [38].

The presence of the TMPRSS2-ERG fusion was detected in 34 out of 108 samples in Czech patients, $(31.5 \%)$ analysed by the RT-qPCR method with UPL probes quantifying mRNA transcripts, with a possibility to measure the expression level, as well [39].The TMPRSS2:ERG rearrangement can be found in about one third of prostate cancers. Saramaki et al. detected that 50 out of 150 $(33 \%)$ of the prostatectomy specimens overexpressed ERG and had TMPRSS2:ERG rearrangement, and in that subgroup they identified prostate cancer patients with good prognosis.[40].

The results that show higher persistence of fusion transcript in prostate cancer samples are obtained in analyses that are conducted on operative material instead of biopsy specimen, and also the researches were in smaller cohort groups.

In our research there were no significant differences between patients with/without detected TMPRSS2-ERG fusion transcript related to Gleason score, as well as no difference between patients with prostate cancer who were with/without detected TMPRSS2-ERG fused transcript related to PSA level.

In Slovenian patients the association between TMPRSS2: ERG fusion and Gleason score before operation was not significant. [41]. In a study of 99 Turkish patients that underwent radical prostatectomy because of prostate cancer, PSA and Gleason were analysed with independent samples t test to predict TMPRSS2-ERG fusion, and none of these variables were found to be statistically significant. [42]
Many studies are conducted to determine if the TMPRSS2-ERG fusion transcript can be associated with the pathogenesis of the prostate carcinoma and if it can be used in early detection, prediction as well as prognosis of this disease [43-53]. However, the significance of this biomarker as a prognostic one is still controversial and further research and analyses are required to detect TMPRSS-ETS and other potential fusion genes of prostate cancer and other solid tumours [54-58].

\section{CONCLUSION}

The latest tissue genome biomarkers are used to assist in the decision making process on the further treatment after the prostate biopsy has been performed offering additional information, and great number of research studies are done, so as to find and isolate the ideal tumour marker that could be relatively easy to determine [59]. The positive findings in small scale studies encourage the implementation of larger scale studies, which will define the positive diagnostic meaning of the TMPRSS-ERG fusion transcript.

From this point of view, the need of researches in bigger cohort groups that are enriched with detection results of genetic transcript in blood and urine, is imposed. In the main research paper, these analyses are still ongoing, and a group of samples obtained by operative procedure as a positive control of the study group is in process of forming.

\section{REFERENCES}

1. Romer, Alfred Sherwood; Parsons, Thomas S. The Vertebrate Body. Philadelphia:Holt-Saunders International; 1977.

2. Mettlin C, Selenkas S, Natarajan N, et al. Beta-caroten, animal fats and prostate cancer risk: a case control study. Cancer 1989; 64: 605-612.

3. Lumey LH, Pittman B, Wynder EL. Alcohol use and prostatae cancer in U.S. whites: no association in a confirmatory study. Prostate 1998; 36(4): 250-255.

4. Hellstrom WJG, ed."Chapter 8: What is the prostate and what is its function?". American Society of Andrology Handbook. San Francisco: American Society of Andrology; 1999. 
5. Shimizu H, Ross RK, Bernstein L, et al.Cancers of the prostate and breast among the Japanese and white immigrants in Los Angeles Country. Br J Cancer 1991; 63: 963-966.

6. Mettlin C. Recent developments in the epidemiology of prostate cancer. Eur JCancer 1997; 33(3): 340-347.

7. Merril RM, Weed DL, Feuer EJ. The lifetime risk of developing prostate cancer in white and black men. Cancer Epidemiol Biomarkers Prev 1997; 6(10): 763-768.

8. Tsukise, A.; Yamada, K. "Complex carbohydrates in the secretory epithelium of the goat prostate". The Histochemical Journal 16 1984; (3): 311-9.

9. Mettlin C, Lee F, Drago J, et al. The American Cancer Society National Prostate Cancer Detection Project. Findings on the detection of early prostate cancer in 2425 men. Cancer 1991; 67: 2949-63.

10. Carroll P, Coley C, McLeod D, et al. Prostate-specific antigen best practice policy--part I: early detection and diagnosis of prostate cancer. Urology 2001; 57: 217-31.

11. Hayes RB, Brown LM, Schoenberg JB et al. Alcohol use and prostate cancer risk in US blacks and whites. Am J epidemiol 1996; 143(7): 692-697.

12. Emami N, Deperthes D, Malm J et al. Major role of human KLK14 in seminal clot liquefaction. J Biol Chem 2008; 283(28): 19561-9.

13. Boyle P, Maisonneuve P, Napalkov B. Incidence of prostate cancer Will double by the year 2030: The Argument For. Eur Urol 1996; 29(suppl 2): 3-9.

14. Terris MK, Peehl DM. Human papilomavirus detection by polymerase chain reaction in benign and malignant prostate tissue is dependent on the primer set utilized. Urology 1997; 50(1): 150-156.

15. SvatekRS, KaramJA, RoehrbornCG, et al.: Preoperative plasma endoglin levels predict biochemical progression after radical prostatectomy.Clin Cancer Res. 2008; 14(11): 3362-3366

16. Andriole GL, Guess HA, Epstein JI, et al. Treatment with finasteride preserves usefulness of prostate-specific antigen in the detection of prostate cancer: results of a randomized, double-blind, placebo-controlled clinical trial. PLESS Study Group. Proscar Long-term Efficacy and Safety Study. Urology 1998; 52: 195-207.

17. Draisma G, Boer R, Otto SJ, et al. Lead times and overdetection due to prostate-specific antigen screening: estimates from the European Randomized Study of Screening for Prostate Cancer. J Natl Cancer Inst 2003; 95: 868-82.

18. Tricoli JV, Schoenfeldt M, Conley BA. Detection of prostate cancer and predicting progression: current and future diagnostic markers. Clin Cancer Res 2004; 10: 3943-50.
19. Coleman MP, Esteve J, Damiecki P et al. Trends in Cancer Incidence and Mortality. Lyon: IARC Scientific Publication No.121; 1993.

20. Boyle P. Prostate cancer 2000: evolution of an epidemic of unknown origin. In: Denis L, ed. Prostate cancer 2000. Heidelberg: Springer - Verlag, 1994: 5-11.

21. Catalona WJ, Smith DS, Ratliff TL, et al. Detection of organ-confined prostate cancer is increased through prostate-specific antigen-based screening. JAMA 1993; 270: 948-53.

22. de Lamirande E., O'Flaherty C. Sperm activation: role of reactive oxygen species and kinases.Biochim Biophys Acta. 2008; 1784: 106-115.

23. ParsonsJK. Modifiable risk factors for benign prostatic hiperplasia and lower urinary tract symptoms : new aproaches to old problems. J Urol 2007; 178(2): 395-401.

24. Jemal A, Siegel R, Ward E et al.: Cancer statistics, 2008. CA Cancer J Clin. 2008; 58(2): 71-96.

25. Brawer MK, Chetner MP, Beatie J, et al. Screening for prostatic carcinoma with prostate specific antigen. J Urol 1992; 147: 841-52.

26. Crawford ED, DeAntoni EP, Etzioni R, et al. Serum prostate-specific antigen and digital rectal examination for early detection of prostate cancer in a national community-based program. The Prostate Cancer Education Council. Urology 1996; 47: 863-74.

27. Draisma G, Etzioni R, Tsodikov A, et al.: Lead time and overdiagnosis in prostate-specific antigen screening: importance of methods and context. J Natl Cancer Inst. 101; 374-383: 2009.

28. Hayes RB, Brown LM, Schoenberg JB et al. Alcohol use and prostate cancer risk in US blacks and whites. Am J epidemiol 1996;143(7): 692-697.

29. Andriole GL, Levin DL, Crawford ED, et al.: Prostate Cancer Screening in the Prostate, Lung, Colorectal and Ovarian (PLCO) Cancer Screening Trial: findings from the initial screening round of a randomized trial. J Natl Cancer Inst. 2005; 97(6): 433-438

30. Anglin IE, Glassman DT, Kyprianou N et al.: Induction of prostate apoptosis by alpha1-adrenoceptor antagonists: mechanistic significance of the quinazoline component. Prostate Cancer Prostatic Dis. 2002; 5(2): 88-95 2002.

31. Coppola V, Musumeci M, Patrizii M, et al. BTG2 loss and miR-21 upregulation contribute to prostate cell transformation by inducing luminal markers expression and epithelial-mesenchymal transition. Oncogene. 2013; 32(14): 1843-1853.

32. Filella X, Foj L. miRNAs as novel biomarkers in the management of prostate cancer. Clin Chem Lab Med. 2017; 55(5): 715-736.

33. Tomlins SA, Laxman B, Dhanasekaran SM, et al. Distinct classes of chromosomal rearrangements 
create oncogenic ETS gene fusions in prostate cancer. Nature. 2007; 448: 595-599.

34. Soller MJ, Isaksson M, Elfving P, et al. Confirmation of the high frequency of the TMPRSS2/ERG fusion gene in prostate cancer. Genes Chromosomes Cancer. 2006; 45: 717-719.

35. Folini M, Gandellini P, Longoni N, et al. miR21: an oncomir on strike in prostate cancer. Mol Cancer. 2010; 9: 12.

36. Mehra R, Tomlins SA, Yu J, et al. Characterization of TMPRSS2-ETS Gene Aberrations in Androgen-Independent Metastatic Prostate Cancer. Cancer Res. 2008; 68: 3584-3590

37. Liu B, Gu X, Huang T, et al. Identification of TMPRSS2-ERG mechanisms in prostate cancer invasiveness: Involvement of MMP-9 and plexin B1. Oncology Reports Jan 2017; 37(1): 201-208.

38. Pettersson A1, Graff RE, Bauer SR, et al. The TMPRSS2:ERG rearrangement, ERG expression, and prostate cancer outcomes: a cohort study and meta-analysis. Cancer Epidemiol Biomarkers Prev. Sep 2012; 21(9): 1497-509.

39. Kulda V, Topolcan O, Kucera R, et al. Prognostic Significance of TMPRSS2-ERG Fusion Gene in Prostate Cancer. Anticancer Research. Sep 2016; 36(9): 4787-4793.

40. Saramäki O.R, Harjula A.E, Martikainen P.M, et al. TMPRSS2:ERG Fusion Identifies a Subgroup of Prostate Cancers with a Favorable Prognosis. Clin Cancer Res. Jun 2008; 14(11): 3395-3400.

41. Krstanoski Z, Kokalj Vokac N, Zagorac A, et al. TMPRSS2:ERG gene aberrations may provide insight into $\mathrm{pT}$ stage in prostate cancer.BMC UROL. 2016 Jul 4; 16(1): 35. doi: 10.1186/s12894-0160160-8.

42. Yılmaz O, Berber U, Okçelik S, et al.TMPRSS2-ERG gene fusion in Turkish patients with localized prostate cancer: results of radical prostatectomy specimens J Urol. 2016 Jun; 42(2): 6063. doi: 10.5152/tud.2016.94763

43. Noonan KL, North S, Bitting RL, et al. Clinical activity of abiraterone acetate in patients with metastatic castration-resistant prostate cancer progressing after enzalutamide. Ann Oncol. 2013; 24(7): 1802-1807.

44. Lapointe J, Kim YH, Miller MA, et al. A variant TMPRSS2 isoform and ERG fusion product in prostate cancer with implications for molecular diagnosis. Mod. Pathol. 2007; 20: 467-473.

45. Cerveira N, Ribeiro FR, Peixoto A, et al. TMPRSS2-ERG gene fusion causing ERG overexpression precedes chromosome copy number changes in prostate carcinomas and paired HGPIN lesions. Neoplasia. 2006; 8: 826-832.
46. Clark J, Merson S, Jhavar S, et al. Diversity of TMPRSS2-ERG fusion transcripts in the human prostate. Oncogene. 2007; 26: 2667-2673.

47. Hermans KG, van Marion $R$, van Dekken $H$, et al. TMPRSS2:ERG fusion by translocation or interstitial deletion is highly relevant in androgen-dependent prostate cancer, but is bypassed in latestage androgen receptor-negative prostate cancer. Cancer Res. 2006; 66: 10658-10663.

48. Iljin K, Wolf M, Edgren H, et al. TMPRSS2 fusions with oncogenic ETS factors in prostate cancer involve unbalanced genomic rearrangements and are associated with HDAC1 and epigenetic reprogramming. Cancer Res. 2006; 66: 1024210246.

49. Perner S, Demichelis F, Beroukhim R, et al. TMPRSS2:ERG fusion-associated deletions provide insight into the heterogeneity of prostate cancer. Cancer Res. 2006; 66: 8337-8341.

50. Wang J, Cai Y, Ren C, et al. Expression of variant TMPRSS2/ERG fusion messenger RNAs is associated with aggressive prostate cancer. Cancer Res. 2006; 66: 8347-8351.

51. Demichelis F, Fall K, Perner S, et al. TMPRSS2:ERG gene fusion associated with lethal prostate cancer in a watchful waiting cohort. Oncogene. 2007; 26: 4596-4599.

52. Mehra R, Tomlins SA, Shen R, et al. Comprehensive assessment of TMPRSS2 and ETS family gene aberrations in clinically localized prostate cancer. Mod. Pathol. 2007; 20: 538-544.

53. Nam RK, Sugar L, Wang Z, et al. Expression of TMPRSS2 ERG gene fusion in prostate cancer cells is an important prognostic factor for cancer progression. Cancer Biol. Ther. 2007; 6: 40-45.

54. Rajput AB, Miller MA, De Luca A, et al. Frequency of the TMPRSS2:ERG gene fusion is increased in moderate to poorly differentiated prostate cancers. J. Clin. Pathol. 2007; 60: 1238-1243.

55. Tomlins SA, Laxman B, Varambally S, et al. Role of the TMPRSS2-ERG gene fusion in prostate cancer. Neoplasia. 2008; 10: 177-188.

56. Kumar-Sinha C, Tomlins SA, Chinnaiyan AM. Recurrent gene fusions in prostate cancer. Nat. Rev. Cancer. 2008; 8: 497-511.

57. Rubin MA. Targeted therapy of cancer: new roles for pathologists-prostate cancer. Mod. Pathol. 2008; 21(Suppl. 2): S44-S55.

58. Stuart RO, Wachsman W, Berry CC, et al. In silico dissection of cell-type-associated patterns of gene expression in prostate cancer. Proc. Natl Acad. Sci. USA. 2004; 101: 615-620.

59. Syed JS, Javier-Desloges J, Tatzel S, et al. Current management strategy for active surveillance in prostate cancer. Curr Oncol Rep. 2017; 19(2): 11. 


\title{
Резиме
}

\section{ДЕТЕКЦИЈА НА ТМРRSS2-ERG ФУЗИРАНИОТ ТРАНСКРИПТ ВО БИОПТИЧЕН ПРИМЕРОК НА ПАЦИЕНТИ СО ПРОСТАТИЧЕН КАНЦЕР: ИСКУСТВО ОД ЕДЕН ЦЕНТАР}

\author{
Александар Трифуновски ${ }^{1}$, Александар Димовски ${ }^{2}$, Сашо Дохчев $^{1}$, Сотир Ставридис $^{1}$ \\ Оливер Станков ${ }^{1}$, Скендер Саиди ${ }^{1}$, Марија Ѓ орѓиевска ${ }^{1}$, Живко Попов ${ }^{1,2}$ \\ ${ }^{1}$ Универзитетска клиника за урологија, Скопје, РС Македонија \\ ${ }^{2}$ Истражувачки центар за генетско инженерство и биотехнологија „Георги Д. Ефремов“, \\ Македонска академија на науките и уметностите, Скопје, РС Македонија
}

Вовед: Карциномот на простата е најчестата малигна неоплазма кај мажите со инциденција што континуирано расте. Фузираниот транскрипт TMPRSS2-ERG води кон андрогена индукција на ERG прото-онкогена експресија и претставува високозастапена онкогена алтерација кај простатичните туморски клетки.

Цел: Цел на истражувањето беше да се детектира и да се евалуира фузираниот транскрипт TMPRSS2-ERG во ткиво на пациентите со карцином на простата и да се воспостави база на материјал од примероците за понатамошни генетски испитувања.

Материјал и методи: Истражувањето претставуваше проспективна клиничка студија, која беше спроведена на прост случаен примерок (random sampling) на 101 пациент (62 со карцином на простата - испитувана група и 39 со бенигна промена на простата - контролна група). За детекција на фузираниот транскрипт TMPRSS2-ERG во простатично ткиво беше изведена Rеal time PCR, a беа користени и податоци од хистопатолошките наоди на ткивата, како и податоци за нивото на ПСА (простато-специфичен антиген) во крвта.

Резултати: Фузираниот транскрипт TMPRSS2-ERG беше детектиран кај 20 од 62 (32, 2 \%) пациенти со карцином на простата, а кај ниеден од пациентите со бенигна промена. Не беше утврдена значајна разлика меѓу пациентите со/без детектирана фузија TMPRSS2-ERG во однос на Gleason скор. Кај 50 \% примероци во испитуваната група овој скор беше повисок од 7 за Median IQR = 7 (6-8). Значајна разлика беше утврдена во просечната вредност на ПСА во прилог на значајно повисоки вредности во испитуваната група кај пациентите со карцином на простата, но не се утврди значајна разлика меѓу пациентите со/без детектирана генска фузија TMPRSS2-ERG во однос на нивото на ПСА.

Дискусија: Резултатите од истражувањето се во согласност со вредностите добиени во анализи реализирани во повеќе истражувачки центри и онколошки институти.

Заклучок: Позитивните наоди во мали студии охрабруваат имплементирање на поголеми студии, дополнети со резултати за генетскиот транскрипт од крв и од урина, кои заедно ќе го дефинираат позитивното дијагностичко значење на фузираниот транскрипт TMPRSS2-ERG.

Клучни зборови: TMPRSS2-ERG, дијагноза, карцином на простата 